\title{
Breast cancer in Angola, molecular subtypes: a first glance
}

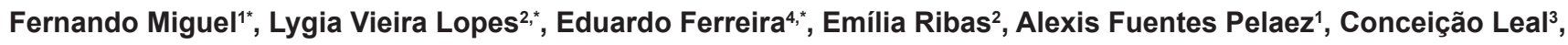 \\ Teresina Amaro5 ${ }^{5}$ Paula Lopes ${ }^{4}$, Cristina Mendes Santos ${ }^{2,6}$, Carlos Lopes ${ }^{5}$ and Lúcio Lara Santos ${ }^{5,6,7, *}$ \\ ${ }^{1}$ Angolan Institute of Cancer Control, Rua Amílcar Cabral, Luanda, Angola \\ ${ }^{2}$ Sagrada Esperança Clinic, Av Murtala Mohammed, Luanda, Angola \\ ${ }^{3}$ Pathology Service, Portuguese Institute of Oncology, Rua António Bernardino de Almeida, Porto 4200-072, Portugal \\ ${ }^{4}$ Eduardo Ferreira Pathology Laboratory, Rua de Camões, 218-5 $5^{\circ}$ andar, Porto 4000-000, Portugal \\ ${ }^{5}$ Experimental Pathology and Therapeutics Group, Portuguese Institute of Oncology, Rua António Bernardino de Almeida, Porto 4200-072, Portugal \\ ${ }^{6}$ ONCOCIR - Education and Care in Oncology - Lusophone Africa, Rua de Quires 168-10J, Moreira da Maia 4470- 643, Portugal \\ ${ }^{7}$ Surgical Oncology Department, Portuguese Institute of Oncology, Rua António Bernardino de Almeida, Porto 4200-072, Portugal
}

Correspondence to: Lúcio Lara Santos. Email: Ilarasantos@gmail.com

*These authors contributed equally to this work.

\section{Abstract}

Purpose: The aim of this study was to investigate the breast cancer (BC) molecular subtypes according to its surrogate immunohistochemistry (IHC) markers. We conducted a preliminary study, to correlate the clinical pathological profiles and molecular subtypes of breast cancer in Luanda, Angola.

Methods: From January 2011 to 30 December 2014, 140 consecutive cases of microscopically confirmed invasive breast carcinoma were classified regarding histology and IHC (ER, PR, HER2, and Ki-67). Surrogate molecular subtypes were classified according to ESMO recommendations.

Results: All patients were female; the median age was 47 years (24-84 years). Invasive carcinoma NST was the most common type (91.4\%) and grade 2 was prevalent (70.7\%). Most tumours were locally advanced (stage III - $65 \%$ and stage IV - 3.6\%). In 140 studied cases, 74 (52.8\%) malignancies were hormone receptor positive; $25.7 \%$ were luminal A like, $19.3 \%$ luminal B and HER2 negative like, $7.9 \%$ luminal B and HER2-positive like, 15.7\% HER2 positive, and 31.4\% were triple negative.

Conclusion: Women's BC in Luanda-Angola is diagnosed at a young age and at an advanced stage. The two predominant molecular subtypes are HR positive and triple negative. The percentage of HER2-positive BC cases was high. Determining the molecular subtype using surrogate IHC markers has important treatment and prognostic implications for Angolan women with BC. There is an urgent need to study a prospective BC series in order to confirm the present results.

Keywords: breast carcinoma, Angola, hormone receptors, molecular subtypes

Published: 30/08/2017

Received: 08/05/2017

ecancer 2017, 11:763 https://doi.org/10.3332/ecancer.2017.763

Copyright: (c) the authors; licensee ecancermedicalscience. This is an Open Access article distributed under the terms of the Creative Commons Attribution License (http://creativecommons.org/licenses/by/3.0), which permits unrestricted use, distribution, and reproduction in any medium, provided the original work is properly cited. 


\section{Background}

The cancer burden in Africa, including Angola, is likely to increase in the forthcoming decades, mostly due to the increasing life expectancy of the population, changes in lifestyles associated with economic development, and longer survival of patients with HIV-receiving antiretroviral therapy, as HIVIAIDS patients have a substantially higher risk of developing cancer than the general population [1].

Countries in sub-Saharan Africa (SSA) are currently undergoing an epidemiological transition and facing the so called 'double-burden' of being affected at the same time by significant infectious and chronic diseases, including malignant tumours [2].

In addition, these countries are confronted with difficulties in cancer diagnosis, stage assessment and access to cancer drugs at affordable prices and of good quality [3]. Therefore, it is crucial to carefully evaluate the profile of oncological diseases in order to avoid treating insufficiently or overtreating patients, bad practices and inadequate allocation of financial resources, while increasing survival.

Breast cancer (BC) is the second most common cancer among women in SSA; however, the incidence rate is clearly increasing [2, 4]. In SSA, BC clinical presentation differs from that in high-income countries mostly due to late-stage disease at presentation, high proportion of young patients (as the African population is predominantly young) as well as very high mortality rates [5]. In Angola, a country with 3600 doctors, 33,000 nurses, 510 pharmacists and close to 3000 health facilities serving a total population of 25.7 million $(65 \%$ less than 24-year old and a life expectancy at birth for women of 63 years according to the National Statistics Institute), a similar trend is observed [6]. In Angola, most BC cases are also diagnosed at advanced stages, at a young age and present low survival rates [7, 8]. In these stages, management of $\mathrm{BC}$ requires an extensive and urgent approach combining actions such as surgery, timely access to cost-effective chemotherapy (cytotoxic, hormone, and target therapies) and/or radiation therapy [9]. The knowledge on BC molecular subtypes may enable more accurate diagnoses and support therapeutic decisions [10]. It is well established that depending on the molecular profile of BC, translated by $\mathrm{IHC}$ characterisation including advanced $\mathrm{BC}$, a set of therapeutic actions should be implemented to minimise the impact of the disease [11, 12]. Molecular subtypes according to its surrogate IHC markers, classify BC into four distinct molecular subtypes: luminal A-like, luminal B-like, HER2 positive and triple negative (TN). Each subtype is associated with different targeted therapies and prognosis [13]. Hormonal treatment, for instance, is effective only in patients whose tumours express oestrogen and/or progesterone receptors (ER, PR). However, the distribution of BC hormonal phenotypes is an area of controversy in Africa. Previous studies suggest that African BC is predominantly of poor hormone receptor (HR) expression [14]. Conversely, a recent systematic review and meta-analysis reported most BC cases in Africa (including SSA) as being HR positive [15]. This discrepancy may reflect real differences, selection bias of cases and/ or problems in laboratory procedures.

The dominant BC molecular profile in Angola is still unknown. To help close this knowledge gap, we conducted a preliminary study to characterise the clinical pathological profiles and molecular-like subtypes of BC in Luanda, Angola.

\section{Methods}

\section{Study population}

Consecutive records of the Angolan Institute of Cancer Control and Clínica Sagrada Esperança, Luanda - Angola, from January 2011 to 30 December 2014, were reviewed by trained doctors and information of BC cases was abstracted using a standard form. Breast tumours were staged according to the 6th edition of TNM classification [16].

\section{Pathology and immunohistochemistry}

Histology was reviewed by expert pathologists according to the WHO 2012 classification (EF, TA, CL) [17].

A total of 179 consecutive cases of microscopically confirmed breast carcinoma were classified using IHC procedures, namely ER, PR, Ki-67 and human epidermal growth factor receptor 2 (HER2). Pre-BC systemic treatment biopsy material or surgical specimens were used for IHC. 
To reduce possible laboratory constraints, duplicate IHC tests were performed in an expert laboratory in Portugal. All cases were reassessed. Of these, 39 cases $(21.8 \%)$ were poorly preserved due to the low quality of the fixation and, therefore, excluded from this analysis. In total, 140 cases were processed.

Standard immunohistochemistry protocols (IHC) were performed using the following: monoclonal ER (clone 6F11, 1:150, Novocastra Laboratories, Leica Microsystems), PR (clone 16, 1:200 Novocastra Laboratories, Leica Biosystems), Ki-67/MIB-1, 1:200, DAKO (Glostrup, Denmark) and HER-2 (1:100, HercepTest DAKO) [18]. The Refine Polymer Detection kit (Leica Microsystems) was used to detect bound antibody, with 3,3-diaminobenzidine as the chromogen (Leica Microsystems). Slides were counterstained with Harris's haematoxylin and results evaluated with positive and negative tissue controls. For ER, PR, and KI-67 antibodies only immunoreactive tumour cell nuclei were counted. Hormonal receptor evaluation was conducted according to the ASCO/CAP guidelines for immunohistochemistry [19]. Ki-67 cut-off point of $15 \%$ was defined according to the experience of different pathologists as well as national and international recommendations [20]. ER- or PR-positive nuclei greater than $1 \%$ were considered hormone receptor positive. High and very high expression of Ki- 67 proliferative index was defined as nuclear expression $\geq 15 \%$ and $\geq 30 \%$ of the tumour cells, respectively.

HER2 - IHC interpretation slides were independently interpreted in a blinded fashion by two pathologists according 2013 ASCO-CAP HER2 Test Guideline Recommendations [21]. Thus, cases interpreted as 0 or $1+$ were considered negative, equivocal cases (2+) were confirmed by SISH according standard procedure and cases 3+ were considered positive [22]. Cases without IHC consensus were reviewed by all pathologists at a multiheaded microscope.

Based on the immunohistochemical results, all cases were classified according to the four BC intrinsic molecular subtypes and their so-called surrogate definition (ESMO recommendations) as: Luminal A-like (ER+ and/or PR+, HER2-, K-67 < 15\%), Luminal B-like (further classified according to HER2 negative: ER+ and/or PR+, HER2-, K-67 $\geq 15 \%$; or HER2 positive: ER+ and/or PR+ HER2+), HER2 positive (RE- and/ or RP- and HER2+) and Triple-negative (RE, RP and HER2 negatives) [23].

\section{Statistical analysis}

A statistical analysis was performed using PASW Statistics for Windows, Version 18.0, 2009. Chicago: SPSS Inc. ®. Descriptive statistics are given as frequencies, median, minimum, and maximum, as interquartile range for continuous variables and as percentages for categorical variables.

\section{Ethics}

Permission to perform this study was given by the Angolan Ministry of Health and corresponding ethics committee.

\section{Results}

As previously mentioned, in $21.8 \%$ of the 179 studied cases, it was not possible to perform IHC studies due to poor preservation of the tissues. The distribution and clinical and pathological characteristics of the excluded cases were similar to the tested sample and did not aggregate a specific group of tumours. Consequently, a total of 140 cases were evaluated. Among these, the median age was 47 years (min. 24 ; max. 84 years. Percentiles 25, 50 and 75 were 39, 47 and 57 years, respectively). Invasive carcinoma of no special-type NST, also known as invasive ductal carcinoma, was the most common type $(91.4 \% ; n=128)$ and grade-2 BC (moderately differentiated) was the most prevalent $(70.7 \% ; n=99)$. Locally advanced carcinomas were found in $68.6 \%$ of patients (91 cases were stage III and 5 cases stage IV). In 74 malignancies (52.8\%), HR were positive. Of these, 42 cases (30\%) were ER and PR positive, 19 cases (13.5\%) were only ER positive, and 13 cases $(9.2 \%)$ were only PR positive representing $7.2 \%$ of all BC cases studied. We found HER2 immunoreactivity $3+$ in 31 cases (22.1\%) and 16 cases were HER2 2+. Therefore, the confirmation of amplification by SISH was performed. In only two of these 16 cases, SISH was positive. Of the $33 \mathrm{HER} 2$ positive, 11 cases $(7.9 \%)$ were HR positive. A total of 44 cases (31.4\%) of BC were triple negative. Overall, regarding BC phenotypes, we found 63 cases (45\%) HR+HER2-, 11 cases (7.9\%) HR+HER2+, 22 cases (15.7\%) HER2+ and 44 cases (31.4\%) TN. 
According to ESMO recommendations for BC molecular subtypes and their surrogate definitions, 36 cases (25.7\%) were luminal A like, 27 (19.3\%) were luminal B - HER2 negative like, 11 (7.9\%) were luminal B - HER2-positive like, 22 (15,7\%) were HER2 positive, and 44 (31,4\%) were triple negative. The detailed description of the collected data is provided in Table 1.

\section{Discussion}

Late motherhood, fewer offspring, late menopause, hormone replacement therapy, obesity and weight gain in adulthood are risk factors usually associated with an increase in HR-positive tumours in post-menopausal women [24]. However, in SSA, these risk factors are not frequent. On the other hand, low socio-economic status, young age at diagnosis, and BRCA1 mutation are more strongly associated with HR-negative tumours, and somewhat closer to SSA reality [25]. Nevertheless, BC molecular subtype's dominant distribution in African populations is still unclear.

Table 1. Association of BC molecular subtypes according to its surrogate IHC markers and clinicopathologic features.

\begin{tabular}{|c|c|c|c|c|c|}
\hline \multirow[t]{2}{*}{ Variable } & \multirow[t]{2}{*}{ Luminal-like $A^{*}$} & \multicolumn{2}{|c|}{ Luminal-like $\mathrm{B}^{*}$} & \multirow[t]{2}{*}{ HER2 positive* } & \multirow[t]{2}{*}{ Triple-negative* } \\
\hline & & HER2 negative & HER2 positive & & \\
\hline Number of cases (\%) & $36(25.7)$ & $27(19.3)$ & $11(7.9)$ & $22(15.7)$ & $44(31.4)$ \\
\hline $\begin{array}{l}\text { Age (years) } \\
\text { Median } \\
\text { Minimum } \\
\text { Maximum }\end{array}$ & $\begin{array}{c}48.5 \\
29 \\
78\end{array}$ & $\begin{array}{c}48.0 \\
24 \\
84\end{array}$ & $\begin{array}{c}41.0 \\
30 \\
68\end{array}$ & $\begin{array}{c}41.0 \\
28 \\
71 \\
\end{array}$ & $\begin{array}{c}47.5 \\
30 \\
83\end{array}$ \\
\hline $\begin{array}{l}\text { Histologic type } \\
\text { Infiltrating ductal carcinoma } \\
\text { Infiltrating lobular carcinoma } \\
\text { Metaplastic carcinoma } \\
\text { Papillary carcinoma } \\
\text { Intracystic papillary carcinoma }\end{array}$ & $\begin{array}{c}32 \\
1 \\
1 \\
1 \\
1\end{array}$ & $\begin{array}{c}26 \\
1 \\
0 \\
0 \\
0\end{array}$ & $\begin{array}{l}11 \\
0 \\
0 \\
0 \\
0\end{array}$ & $\begin{array}{l}22 \\
0 \\
0 \\
0 \\
0\end{array}$ & $\begin{array}{l}40 \\
3 \\
1 \\
0 \\
0\end{array}$ \\
\hline $\begin{array}{l}\text { Grade } \\
1 \\
2 \\
3\end{array}$ & $\begin{array}{c}5 \\
27 \\
4\end{array}$ & $\begin{array}{c}3 \\
22 \\
2\end{array}$ & $\begin{array}{l}0 \\
6 \\
5\end{array}$ & $\begin{array}{c}0 \\
13 \\
9\end{array}$ & $\begin{array}{c}0 \\
26 \\
18\end{array}$ \\
\hline $\begin{array}{l}\text { Stage } \\
\text { I } \\
\text { Ila } \\
\text { Ilb } \\
\text { IIla } \\
\text { IIlb } \\
\text { IIlc } \\
\text { IV } \\
\text { NA }\end{array}$ & $\begin{array}{c}0 \\
3 \\
9 \\
11 \\
5 \\
5 \\
2 \\
1\end{array}$ & $\begin{array}{c}0 \\
3 \\
2 \\
12 \\
6 \\
1 \\
1 \\
2\end{array}$ & $\begin{array}{l}0 \\
1 \\
1 \\
3 \\
4 \\
1 \\
1 \\
0\end{array}$ & $\begin{array}{l}1 \\
2 \\
3 \\
6 \\
5 \\
1 \\
1 \\
3\end{array}$ & $\begin{array}{c}0 \\
3 \\
8 \\
17 \\
13 \\
1 \\
0 \\
2\end{array}$ \\
\hline $\begin{array}{l}\text { Hormone receptors } \\
\text { Positive } \\
\text { Negative }\end{array}$ & $\begin{array}{c}36 \\
0\end{array}$ & $\begin{array}{c}27 \\
0 \\
\end{array}$ & $\begin{array}{c}11 \\
0 \\
\end{array}$ & $\begin{array}{c}0 \\
22 \\
\end{array}$ & $\begin{array}{c}0 \\
44 \\
\end{array}$ \\
\hline $\begin{array}{l}\mathbf{K i}-67 \\
<15 \% \\
15-30 \% \\
>30 \%\end{array}$ & $\begin{array}{c}36 \\
0 \\
0\end{array}$ & $\begin{array}{c}0 \\
24 \\
3\end{array}$ & $\begin{array}{l}0 \\
8 \\
3\end{array}$ & $\begin{array}{c}8 \\
11 \\
3\end{array}$ & $\begin{array}{c}27 \\
13 \\
4\end{array}$ \\
\hline
\end{tabular}

${ }^{*}$ According ESMO recommendations [22].

NA - Not announced. 


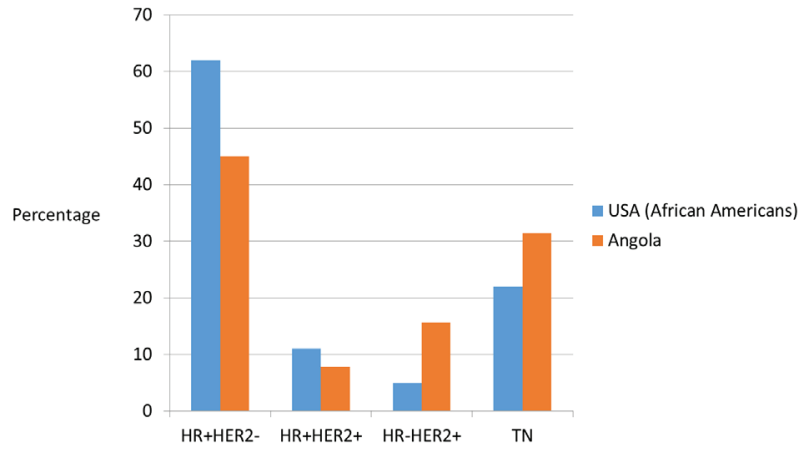

Figure 2. Distribution of breast cancer phenotype in United States African-American population [27] and Angola population (our study).

To the best of our knowledge, this is the first report on receptor-defined subtypes of BC in indigenous populations of Angola and it is a contribution to clarify the SSA profile of BC receptor status.

Angola is characterised by a high prevalence of late stage BC at diagnosis, which occurs at young age. As observed in most SSA countries invasive carcinoma (NST) and high histologic grade are predominant [5, 26].

In our study, relatively high rates of TN and HER2-positive cases were identified; however, HR+/HER2- phenotype was predominant, similarly to what happens in the African-American population (Figure 2) [27]. According to the 2015 St Gallen Consensus Conference and ESMO surrogate definitions of BC molecular subtypes, in our series, $25.7 \%$ were luminal A like, $19.3 \%$ were luminal B - HER2-negative like, $7.9 \%$ were luminal B - HER2-positive like, 15,7\% were HER2 positive and 31,4\% were triple negative. The rate of oestrogen receptor negative/progesterone receptor- ositive was $7.2 \%$ of all BC cases studied, somewhat higher than is usually described. Several previous studies have shown ER negative/PR positive class constitutes $2-7 \%$ of breast cancer [28]. Shen T et al. found that the ER/PR+ rate was higher in African Americans than in the white population, these patients were young and had high-grade and aggressive tumours [29]. Our cases were predominantly high grade and occurred in young pre-menopausal women similar to that recorded by others [29, 30]. Immunohistochemical studies were repeated and we had consistent results. However, De Maeyer et al. indicates that the use of different thresholds for positivity and technical sensitivity in the different studies may obscure the results and their comparison [28, 31]. Consequently, further confirmatory studies are recommended. To evaluate our results, we have thoroughly reviewed the studies carried out in SSA.

Thereby, McCormack V et al. studied 1200 South African patients and found that the majority of tumours were ER positive in black patients, triple-negative cases constituted one fifth of tumours, black women were more likely than non-black women to have ER negative or triple negative, and the HER2+ proportions were relatively high [32]. Dickens $\mathrm{C}$ et al. studied ER, PR and HER2 receptor status in two multiracial Southern African countries (South Africa and Namibia) with routine diagnostic IHC and concluded that positive ER breast cancer dominates in all Southern African races [33]. However, different results were observed in other regions of Africa. For instance, Titloye et al. studied a total of 835 tumours from Nigerian patients and the predominant molecular phenotype found was triple-negative type (47.6\%) followed by the HER2positive group (19.6\%) [34]. Rambau P et al. found, in North-Western Tanzanian BC patients, a low level of expression of HR and a significant proportion of triple negative [35]. Luyeye Mvila G et al. compared a BC series diagnosed in Kinshasa (Africans) with a European series of BC diagnosed in Leuven and found that the first group presented BC at younger ages and mainly ER-negative and HER2-positive tumours, when compared to the Caucasian group. However, no difference in the rate of triple-negative BC was observed [36]. Ly M et al. found a high incidence of aggressive triple-negative tumours in Mali [37]. A study comprising 507 patients diagnosed with breast cancer between 1996 and 2007 at six geographic regions in Nigeria and Senegal showed that $76 \%$ of cases were ER negative [38]. In Lusaka, Anastase Nkuliyingoma (2015) studied 46 patients with BC and found ER negative in $54.3 \%$, PR negative in $47.8 \%$ and $4.3 \%$ HER2 positive [39]. In Ghana, divergent results were observed. Adjei EK et al. studied $51 \mathrm{BC}$ cases, of which $76 \%$ were $\mathrm{ER}+(\geq 1 \%$ ER+ tumour cells) and $22 \%$ were triple negative [40]. However, in Kumasi, BC affects mostly young pre-menopausal women who presented advanced disease. Of the 54 BC cases studied, $47 \%, 13.2 \%$, and $20.2 \%$ were positive for ER, PR, and HER2 (3+), respectively, and $42.7 \%$ were triple negative [41].

With the aim of clarifying these differences, Jamal and Fedewa reported that the prevalence of BC-negative HR in US-born black women was similar to BC in African patients from Western Africa living in the USA and in Caribbean black women. The prevalence of BC-negative HR was substantially lower in BC of black women born in East Africa and living in the USA [42]. Curiously, Kantelhardt EJ et al. verified that only 35\% 
of the cases were ER negative in Ethiopia (an East African country) and the proportion of ER-negative tumours decreased with advancing age at diagnosis and was not affected by histology or stage [43]. Corroborating this data, a study conducted in Kenya (an East African country) by Syed $S$ et al. presented a definitive prospective analysis of ER/PR/HER2 from a single centre and demonstrated that the prevalence of receptor status was comparable with that in the West [44]. Our results and abovementioned studies regarding ER negative were aggregated in Figure 1. In Table 2, we compare our results with the available SSA breast cancer phenotype data [32-34, 36, 38, 44-46]. We found that results from Luanda, Angola are quite similar to those described in neighbouring countries.

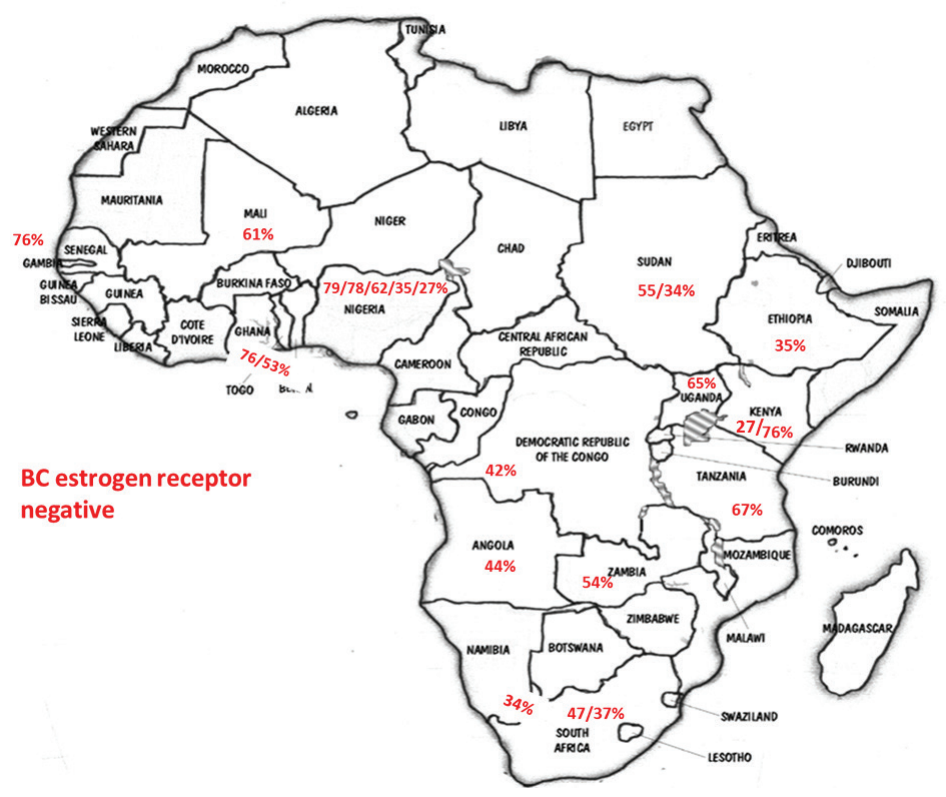

Figure 1. Percentage of negative oestrogen receptor in different SSA countries according to the data of studies referenced in this paper as well as our results (BC - breast cancer).

Table 2. Results of studies with data on surrogate molecular breast cancer subtypes in indigenous populations in sub-Saharan Africa.

\begin{tabular}{|c|c|c|c|c|c|}
\hline Study & Country & $\begin{array}{l}\text { Luminal A-like } \\
\text { number (\%) }\end{array}$ & $\begin{array}{l}\text { Luminal B-like } \\
\text { number }(\%)\end{array}$ & $\begin{array}{l}\text { HER2+ } \\
\text { number (\%) }\end{array}$ & $\begin{array}{l}\text { Triple-negative } \\
\text { number }(\%)\end{array}$ \\
\hline Huo D et al [38] & Nigeria and Senegal & $102(37.7)$ & $9(3.32)$ & $57(21.03)$ & $103(38.0)$ \\
\hline Agboola AJ et al [45] & Nigeria & $48(26.1)$ & $10(5.4)$ & $34(18.5)$ & $69(37.5)$ \\
\hline Titloye NA et al [34] & Nigeria & $70(15.0)$ & $26(5.0)$ & $92(20.0)$ & $279(48.0)$ \\
\hline $\begin{array}{l}\text { Adebamowo CA et al } \\
{[46]}\end{array}$ & Nigeria & $118(77.6)$ & $4(2.6)$ & $6(4.0)$ & $24(15.8)$ \\
\hline Luyeye MG et al [36] & $\begin{array}{l}\text { Democratic Republic } \\
\text { of Congo }\end{array}$ & $54(62.07)$ & $13(14.94)$ & $7(8.05)$ & $13(14.94)$ \\
\hline Our study & Angola & $63(45.0)$ & $11(7.9)$ & $22(15.7)$ & 44 (31.4) \\
\hline Dickens C et al [33] & $\begin{array}{l}\text { South Africa and } \\
\text { Namibia }\end{array}$ & $2416(54.6)$ & $610(13.8)$ & $474(10.7)$ & $925(20.9)$ \\
\hline $\begin{array}{l}\text { McCormack VA et al } \\
\text { [32] }\end{array}$ & South Africa & $551(53.7)$ & $150(14.6)$ & $117(11.04)$ & $209(20.4)$ \\
\hline Sayed S et al [44] & Kenya & $175(61.2)$ & $31(10.8)$ & $22(7.7)$ & $58(20.2)$ \\
\hline
\end{tabular}

Luminal A-like (HR+HER2-); Luminal B-like (HR+HER2+); HER2+ (HR-HER2+) and TN (HR-HER2-). HR (hormone receptors), HER2 (HER 2 receptors) and TN (triple negative). 
Given the above, could the diversity found between West and East Africa regarding HR and HER2 expression rate in BC be also explained by the African population migrations? [47, 48]. Do these migration aspects have any influence in our results? Is it reasonable to hypothesise that poor survival in SSA countries may also be related to the presence of indigenous poor prognostic factors? There is no doubt that Ethno-oncology is a challenging field to be developed in the future. Molecular markers of breast cancer should be investigated in multiethnic populations to determine their role as therapy targets, predictors or prognostic indicators of disease [49]. As pointed out by Eng A et al. no single-molecular BC subtype dominates in Africa [15]. Consequently, receptor testing availability should be a priority, in order to offer the best $\mathrm{BC}$ treatment modalities.

Finally, some methodological limitations of the present study should be mentioned. Due to sample size constraints and the absence of data provided by other municipalities in Angola, the presented results may not be representative of the Angolan female population with BC and results should only be generalised to women treated in Luanda. Another aspect to be noted refers to the fact that 39 cases $(21.8 \%)$ were poorly preserved. Nonetheless, the distribution of these cases was random and did not aggregate a specific group of tumours, and therefore did not compromise the obtained results.

\section{Conclusion}

Women with BC in Luanda-Angola are diagnosed at a young age and at an advanced stage. The two predominant molecular subtypes are HR positive and triple negative. The percentage of HER2-positive BC cases was high. Determining the molecular subtype using surrogate IHC markers has important treatment and prognostic implications for Angolan women with BC. There is an urgent need to study a prospective $\mathrm{BC}$ series in order to confirm the present results in a more representative sample of the Angolan population.

\section{Conflicts of interest}

No conflicts of interest to disclose. No financial or commercial relationships.

\section{Authors' contributions}

This study was conceptualised, designed, and written by Lúcio Lara Santos. Acquisition of data was carried out by Fernando Miguel, Lygia Vieira Lopes, Emilia Ribas, Alexis Fuentes Pelaez, Paula Lopes and Lúcio Lara Santos. Analysis, and interpretation of data were done by Eduardo Ferreira, Teresina Amaro, Carlos Lopes, Conceição Leal, Cristina Santos and Lúcio Lara Santos. Fernando Miguel, Lygia Vieira Lopes, Eduardo Ferreira, Emília Ribas, Alexis Fuentes Pelaez, Conceição Leal, Teresina Amaro, Paula Lopes, Cristina Santos, Carlos Lopes, and Lúcio Lara Santos drafted or revised the article for important intellectual content. All authors read and agreed to the final version of this manuscript. Fernando Miguel, Eduardo Ferreira, Lygia Vieira Lopes, and Lúcio Lara Santos equally contributed to this study.

\section{Acknowledgments}

The authors thank Clara Castro for proofreading the paper.

\section{References}

1. Soerjomataram I, Lortet-Tieulent J, and Parkin DM, et al (2012) Global burden of cancer in 2008: a systematic analysis of disability-adjusted life-years in 12 world regions Lancet 24 1840-1850 https://doi.org/10.1016/S0140-6736(12)60919-2

2. GBD 2015 Risk Factors Collaborators (2016) Global, regional, and national comparative risk assessment of 79 behavioural, environmental and occupational, and metabolic risks or clusters of risks, 1990-2015: a systematic analysis for the Global Burden of Disease Study 2015 Lancet 8 1659-1724 
3. Ndom P (2008) Challenges of anticancer chemotherapy in Africa Can J Urol 15 3909-3911 PMID: 18304402

4. Jemal A, Bray F, and Center MM, et al (2011) Global cancer statistics CA Cancer J Clin 2 69-90 https://doi.org/10.3322/caac.20107

5. Jedy-Agba E, McCormack V, and Adebamowo C, et al (2016) Stage at diagnosis of breast cancer in sub-Saharan Africa: a systematic review and meta-analysis Lancet Glob Health 4 e923-e935 https://doi.org/10.1016/S2214-109X(16)30259-5 PMID: $\underline{27855871}$

6. Ceita C (2016) Resultados definitivos: Recenseamento geral da população e habitação - 2014. INE Luanda, Angola file:///C:/ Users/i11637/Desktop/AngolaCensus2014_ResultadosDefinitivos_Mar2016.pdf

7. Armando A, Bozzetti MC, and de Medeiros Zelmanowicz A, et al (2015) The epidemiology of cancer in Angola-results from the cancer registry of the national oncology centre of Luanda, Angola Ecancermedicalscience 17 510-520

8. Lopes LV, Miguel F, and Freitas H, et al (2015) Stage at presentation of breast cancer in Luanda, Angola - a retrospective study BMC Health Serv Res 15 471-478 https://doi.org/10.1186/s12913-015-1092-9 PMID: 26471845 PMCID: 4608221

9. Anderson BO, Ilbawi AM, and El Saghir NS (2015) Breast cancer in low and middle income countries (LMICs): a shifting tide in global health Breast $\mathrm{J} 21$ 111-118 https://doi.org/10.1111/tbj.12357

10. Cardoso F, van't Veer LJ, and Bogaerts J, et al (2016) 70-gene signature as an aid to treatment decisions in early-stage breast cancer N Engl J Med 25 717-729 https://doi.org/10.1056/NEJMoa1602253

11. Cardoso F, Costa A, and Senkus E, et al (2017) 3rd ESO-ESMO International Consensus Guidelines for Advanced Breast Cancer (ABC 3) Ann Oncol 28 16-33 PMID: 28177437 PMCID: $\underline{5378224}$

12. Spitale A, Mazzola P, and Soldini D, et al (2009) Breast cancer classification according to immunohistochemical markers: clinicopathologic features and short-term survival analysis in a population-based study from the South of Switzerland Ann Oncol 20 628-635 https://doi.org/10.1093/annonc/mdn675

13. Yersal O, Barutca S (2014) Biological subtypes of breast cancer: prognostic and therapeutic implications World J Clin Oncol 5 412-424 https://doi.org/10.5306/wjco.v5.i3.412 PMID: 25114856 PMCID: 4127612

14. Bird PA, Hill AG, Houssami N (2008) Poor hormone receptor expression in East African breast cancer: evidence of a biologically different disease? Ann Surg Oncol 15 1983-1988. https://doi.org/10.1245/s10434-008-9900-7 PMID: 18408976

15. Eng A, McCormack $V$, dos-Santos-Silva I (2014) Receptor-defined subtypes of breast cancer in indigenous populations in Africa: a systematic review and meta-analysis PLoS Med 11 e1001720 https://doi.org/10.1371/journal.pmed.1001720 PMID: 25202974 PMCID: 4159229

16. Singletary SE, Connolly JL (2006) Breast cancer staging: working with the sixth edition of the AJCC Cancer Staging Manual $C A$ Cancer J Clin 56 37-47 https://doi.org/10.3322/canjclin.56.1.37 PMID: 16449185

17. Lakhani S, Ellis I, and Schnitt S, et al (2012) WHO Classification of Tumours of the Breast $4^{\text {th }}$ edn (Lyon: IARC Press)

18. Williams SL, Birdsong GG, and Cohen C et al (2009) Immunohistochemical detection of estrogen and progesterone receptor and HER2 expression in breast carcinomas: comparison of cell block and tissue block preparations Int $J$ Clin Exp Pathol 2 476-480 PMID: 19294006 PMCID: 2655151

19. Hammond ME, Hayes DF, and Dowsett M, et al (2010) Guideline recommendations for immunohistochemical testing of estrogen and progesterone receptors in breast cancer Arch Pathol Lab Med 134 907-922 PMID: 20524868 PMCID: 3073033

20. Inwald EC, Klinkhammer-Schalke M, and Hofstädter F, et al (2013) Ki-67 is a prognostic parameter in breast cancer patients: results of a large population-based cohort of a cancer registry Breast Cancer Res Treat 139 539-552 https://doi.org/10.1007/ s10549-013-2560-8 PMID: 23674192 PMCID: $\underline{3669503}$ 
21. Wolff $A C$, Hammond ME, and Hicks DG, et al (2013) Recommendations for human epidermal growth factor receptor 2 testing in breast cancer: American Society of Clinical Oncology/College of American Pathologists clinical practice guideline update $J$ Clin Oncol 31 3997-4013 https://doi.org/10.1200/JCO.2013.50.9984 PMID: 24101045

22. Polonia A, Leitão D, Schmitt F (2016) Application of the 2013 ASCO/CAP guideline and the SISH technique for HER2 testing of breast cancer selects more patients for anti-HER2 treatment Virchows Arch 468 417-423 https://doi.org/10.1007/s00428-0161903-3 PMID: 26754674

23. Senkus E, Kyriakides S, and Ohno S, et al (2015) ESMO Guidelines Committee. Primary breast cancer: ESMO Clinical Practice Guidelines for diagnosis, treatment and follow-up Ann Onco/ Suppl. 5 v8-v30 https://doi.org/10.1093/annonc/mdv298

24. Fuentes-Mattei E, Velazquez-Torres G, and Phan L, et al (2014) Effects of obesity on transcriptomic changes and cancer hallmarks in estrogen receptor-positive breast cancer J Natl Cancer Inst 106 (7) 1-12 https://doi.org/10.1093/jnci/dju158

25. Paluch-Shimon S, Pagani O, and Partridge AH, et al (2016) Second international consensus guidelines for breast cancer in young women (BCY2) Breast 26 87-99 https://doi.org/10.1016/j.breast.2015.12.010 PMID: 27017247

26. Vanderpuye V, Grover S, and Hammad N, et al (2017) An update on the management of breast cancer in Africa Infect Agent Cancer 12 13-25 https://doi.org/10.1186/s13027-017-0124-y PMID: 28228841 PMCID: $\underline{5307840}$

27. DeSantis CE, Fedewa SA, and Goding Sauer A, et al (2016) Breast cancer statistics, 2015: Convergence of incidence rates between black and white women CA Cancer J Clin 66 31-42 https://doi.org/10.3322/caac.21320

28. Emad A. Rakha, and lan O. Ellis (2008) In reply J Clin Oncol 26 336-338

29. Shen T, Brandwein-Gensler M, and Hameed O, et al (2015) Characterization of estrogen receptor-negative/progesterone receptor-positive breast cancer Hum Pathol 46 1776-1784 https://doi.org/10.1016/j.humpath.2015.07.019 PMID: 26363528

30. Rakha EA, El-Sayed ME, and Green AR, et al (2007) Biologic and clinical characteristics of breast cancer with single hormone receptor positive phenotype $J$ Clin Oncol 25 4772-4778 https://doi.org/10.1200/JCO.2007.12.2747 PMID: 17876012

31. Leen De Maeyer, Erik Van Limbergen, and Katelijne De Nys (2008) Doesestrogen receptor-negative/progesterone receptorpositive breast carcinoma exist? J Clin Oncol 26 335-336 https://doi.org/10.1200/JCO.2007.14.8411

32. McCormack VA, Joffe M, and van den Berg E, et al (2013) Breast cancer receptor status and stage at diagnosis in over 1,200 consecutive public hospital patients in Soweto, South Africa: a case series Breast Cancer Res 15 R84 https://doi.org/10.1186/ bcr3478 PMID: 24041225 PMCID: $\underline{3978918}$

33. Dickens C, Duarte R, and Zietsman A, et al (2014) Racial comparison of receptor-defined breast cancer in Southern African women: subtype prevalence and age-incidence analysis of nationwide cancer registry data Cancer Epidemiol Biomarkers Prev 23 2311-2321 https://doi.org/10.1158/1055-9965.EPI-14-0603 PMID: 25143359

34. Titloye NA, Foster A, and Omoniyi-Esan GO, et al (2016) Histological features and tissue microarray taxonomy of Nigerian breast cancer reveal predominance of the high-grade triple-negative phenotype Pathobiology $8324-32$ https://doi. org/10.1159/000441949 PMID: 26730581

35. Rambau P, Masalu N, and Jackson K, et al (2014) Triple negative breast cancer in a poor resource setting in North-Western Tanzania: a preliminary study of 52 patients BMC Res Notes 7 399-445 https://doi.org/10.1186/1756-0500-7-399 PMID: 24964871 PMCID: 4081017

36. Luyeye MG, Batalansi D, and Praet M, et al (2015) Prognostic features of breast cancer differ between women in the Democratic Republic of Congo and Belgium Breast 24 642-648 https://doi.org/10.1016/j.breast.2015.07.031

37. Ly M, Antoine M, and Dembélé A, et al (2012) High incidence of triple-negative tumors in sub-Saharan Africa: a prospective study of breast cancer characteristics and risk factors in Malian women seen in a Bamako University Hospital. Oncology 83 257-263 https://doi.org/10.1159/000341541 PMID: 22964749 
38. Huo D, Ikpatt F, and Khramtsov A, et al (2009) Population differences in breast cancer: survey in indigenous African women reveals over-representation of triple-negative breast cancer J Clin Oncol 27 4515-4521 https://doi.org/10.1200/JCO.2008.19.6873 PMID: 19704069 PMCID: 2754904

39. Nkuliyingoma A (2015) Effect of oestrogen receptor status of women with breast cancer treated with tamoxifen at University Teaching Hospital and Cancer Diseases Hospital Available at: http://dspace.unza.zm:8080/xmlui/bitstream/handle/123456789/4364/ Dr\%20Nkhuliyingoma_dissertation.pdf? sequence=1\&isAllowed=y

40. Adjei EK, Owusu-Afriyie O, and Awuah B, et al (2014) Hormone receptors and Her2 expression in breast cancer in sub-Saharan Africa A comparative study of biopsies from Ghana and Norway Breast J 20 308-311 https://doi.org/10.1111/tbj.12261 PMID: $\underline{24708149}$

41. Ohene-Yeboah M, Adjei E (2012) Breast cancer in Kumasi, Ghana Ghana Med J 46 8-13 PMID: 22605883 PMCID: $\underline{3353503}$

42. Jemal A, Fedewa SA (2012) Is the prevalence of ER-negative breast cancer in the US higher among Africa-born than US-born black women? Breast Cancer Res Treat 135 867-873 https://doi.org/10.1007/s10549-012-2214-2 PMID: 22915073

43. Kantelhardt EJ, Mathewos A, and Aynalem A, et al (2014) The prevalence of estrogen receptor-negative breast cancer in Ethiopia BMC Cancer 14 895-901 https://doi.org/10.1186/1471-2407-14-895 PMID: 25433805 PMCID: 4258259

44. Sayed S, Moloo Z, and Wasike R, et al (2014) Is breast cancer from Sub Saharan Africa truly receptor poor? Prevalence of ER/ PR/HER2 in breast cancer from Kenya Breast 23 591-596 https://doi.org/10.1016/j.breast.2014.06.006 PMID: 25012047

45. Agboola AJ, Musa AA, and Wanangwa N, et al (2012) Molecular characteristics and prognostic features of breast cancer in Nigerian compared with UK women Breast Cancer Res Treat 135 555-569 https://doi.org/10.1007/s10549-012-2173-7 PMID: 22842985

46. Adebamowo CA, Famooto A, and Ogundiran TO, et al (2008) Immunohistochemical and molecular subtypes of breast cancer in Nigeria Breast Cancer Res Treat 110 183-188 https://doi.org/10.1007/s10549-007-9694-5

47. Camtbell MC, Tishkoff SA (2008) African genetic diversity: implications for human demographic history, modern human origins, and complex disease mapping Annu Rev Genomics Hum Genet 9 403-433 https://doi.org/10.1146/annurev.genom.9.081307.164258

48. Coelho M, Sequeira F, and Luiselli D, et al (2009) On the edge of Bantu expansions: mtDNA, Y chromosome and lactase persistence genetic variation insouthwestern Angola BMC Evol Biol 9 80-98 https://doi.org/10.1186/1471-2148-9-80

49. Perera NMA, Gui GPH (2003) Multi-ethnic differences in breast cancer: current concepts and future directions Int J Cancer 106 463-467 https://doi.org/10.1002/ijc.11237 PMID: 12845638 